UDC 616.36-008.5-036.1-089.48:612.35

https://doi.org/10.26641/2307-0404.2020.1.200415

\author{
O.B. Kutovyi, \\ D.V. Balyk, \\ D.O. Kysilevskyi
}

\title{
FUNCTIONAL STATE OF THE LIVER AFTER EXTERNAL DRAINAGE OF BILE DUCTS IN PATIENTS WITH A HIGH LEVEL OF OBSTRUCTIVE JAUNDICE
}

\author{
$S E$ «Dnipropetrovsk medical academy of Health Ministry of Ukraine» \\ Department of Surgery $N 2$ \\ V. Vernadsky str., 9, Dnipro, 49044, Ukraine \\ Д3 «Дніпропетровська медична академія МОЗ Украӥни» \\ кафедра хірургї̈ № 2 \\ (зав. - д. мед. н., проф., О.Б. Кутовий) \\ вул. В. Вернадського, 9, Дніпро, 49044, Украӥна \\ e-mail: balikdmitriy@gmail.com
}

\author{
Цитування: Медичні перспективи. 2020. Т. 25, № 1. С. 150-156 \\ Cited: Medicni perspektivi. 2020;25(1):150-156
}

Key words: high level of obstructive jaundice, external drainage of bile ducts, poor bile flow (debit), liver status Ключові слова: тяжка механічна жовтяниця, зовнішнє дренування жовчних протоків, дебіт жовчі, функція печінки

Ключевые слова: тяжелая механическая желтуха, наружное дренирование желчных протоков, дебит желчи, функция печени

\begin{abstract}
Functional state of the liver after external drainage of bile ducts in patients with a high level of obstructive jaundice. Kutovyi O.B., Balyk D.V., Kysilevskyi D.O. The results of the examination and treatment of 67 patients with a high level of obstructive jaundice were analyzed. Diagnosis of obstructive jaundice syndrome was based on the data of anamnesis, complaints, physical, laboratory and instrumental research methods. Among the latter we performed ultrasound investigation (USI) of abdominal organs and bile ducts as a screening method, fibrogastroduodenoscopy (FGDS), computed tomography(CT), magnetic resonance cholangiopancreatography (MRCPG) was carried out if necessary. The cause of a high level of obstructive jaundice: pancreatic head cancer - 27 (40.3\%); choledocholithiasis - 21 (31.3\%); Klatskin tumour - 5 (7.5\%); cancer of the large duodenal papilla - 4 (6.0\%); chronic pseudotumor pancreatitis - 4 (6.0\%); choledoch cancer - 3 (4.5\%); choledochal stricture - 3 (4.5\%). The first stage of treatment started from the implementation of percutaneous and hepatic external drainage of the bile ducts under ultrasound control. The functional state of the liver was evaluated according to the level of total bilirubin and its fractions, aspartate aminotransferase (AST), alanine aminotransferase (ALT) and alkaline phosphatase (ALP). The researches were performed at the admission of patients to the clinic and on day 1, 3 and 7 after external drainage of the bile ducts. Patients were divided into 2 groups, depending on the bile flow rate on the first day after decompression of the biliary tract. It was concluded that the degree of hepatitis in the early period after the performed procedure is directly associated with the bile flow rate during the first day after external drainage of the bile ducts.
\end{abstract}

Реферат. Функціональний стан печінки після зовнішнього дренування жовчних протоків у хворих на тяжку механічну жовтяницю. Кутовий О.Б., Балик Д.В., Кисілевський Д.О. Проаналізовані результати обстеження і лікування 67 хворих з тяжкою механічною жовтяницею. Діагностика синдрому механічної жовтяниці базувалася на даних анамнезу, скаргах, фізикальних, лабораторних та інструментальних методах дослідження. Серед останніх проводили ультразвукове дослідження (УЗД) органів черевної порожнини та жовчних протоків як скрнинінговий метод, фіброгастродуоденоскопію (ФГДС), комп'ютерну томографію (КТ), магнітно-резонансну холангіопанкреатографію (МРХПГ) у разі необхідності. Причиною тяжкої механічної жовтяниці були: рак головки підилункової залози - 27 (40,3\%); холедохолітіаз - 21 (31,3\%); пухлина Клатскіна - 5 (7,5\%); рак великого дуоденального сосочка - 4 (6,0\%); хронічний псевдотуморозний панкреатит - 4 (6,0\%); рак холедоха - 3 (4,5\%); стриктура холедоха - 3 (4,5\%). Периий етап лікування хворих починали з виконання черезшкірно-черезпечінкового зовнішнього дренування жовчних протоків під УЗ контролем. Оцінювали функціональний стан печінки за рівнем загального білірубіну $і$ його фракцій, аспартатамінотрансферази (АСТ), аланінамінотрансферази (АЛТ) та лужної фосфатази (ЛФ). Дослідження проводили при надходженні хворих до клініки та на 1, 3 та 7 добу після зовнішнього дренування жовчних протоків. Хворі були розподілені на 2 групи залежно від дебіту жовчі в периу добу після декомпресіі біліарного тракту. Дійтли висновку, щзо ступінь гепатаргії в ранньому періоді після виконаної процедури прямо пов'язаний з дебітом жовчі протягом першої доби після зовнішнього дренування жовчних протоків. 
Problems of timely diagnosis and effective treatment of pancreatic biliary diseases, which are complicated by the development of the high level of obstructive jaundice presently remain relevant and in the most cases they are not solved [5, 9]. Nowdays a lot of authors tend to the two-stage tactics for treating this pathology. The results of treatment of high level of obstructive jaundice depend on the prescription hyperbilirubinemia duration, the level and causes of bile duct obturation [3, 4, 10]. Surgical interventions which are performed in the first stage, at the height of jaundice, are directed to the decompression of the biliary tract and the elimination of jaundice $[1,2,6]$. At the same time, presently there are no clear notions about liver functions after external drainage of bile ducts on the background of the high level of obstructive jaundice and the prevention of liver failure, as a consequence of the rapid decompression of the biliary tract syndrome $[8,11]$.

The purpose of the study was to estimate the functional status of the liver in patients with the high level of obstructive jaundice depending on poor bile flow (debit) on the first day after external drainage of the biliary tracts.

\section{MATERIALS AND METHODS OF RESEARCH}

From the general group of patients with a high level of obstructive jaundice, who were on treatment in I.I. Mechnikov Regional Clinical Hospital in the city Dnipro, 67 patients aged 45 to 77 years were selected. Among them there were $38(56.7 \%)$ women and $29(43.3 \%)$ men. The average age of the patients was $64.4 \pm 12.1$ years. The criterion for exclusion were viral hepatitis, portal hypertension, concomitant cardiac pathology and the age over 80 years.

The causes of the high level of obstructive jaundice were: pancreatic head cancer - $27(40.3 \%)$; choledocholithiasis - 21 (31.3\%); Klatskin tumour $5(7.5 \%)$; cancer of the large duodenal papilla $4(6.0 \%)$; chronic pseudotumorosis pancreatitis $4(6.0 \%)$; choledoch cancer $-4.3 \%(95 \%$ CI 1.8 $6.1)$; stricture of choledochus -3 (4.5\%).

Diagnosis of mechanical jaundice syndrome was based on the data of anamnesis, complaints and physical, laboratory and instrumental research methods. Patients underwent ultrasound investigation (USI) of the abdominal organs and bile ducts as a scrining method, fibrogastroduodenoscopy (FGDS), computed tomography (CT), magnetic resonance cholangiopancreatography (MRCPG), if necessary. Assessment of the functional state of the liver was performed according to the level of total bilirubin in the serum of blood and its fractions, aspartate aminotransferase (AST), alanine aminotransferase (ALT), alkaline phosphatase (ALP).
The first stage of treatment started from drainage of the bile duct under ultrasound control. Drainages were presented by Fr10 tubes of 9 and 8 diameters. In case of cholangitis antibacterial drugs were prescribed. The functional state of the liver was examined on admission, on the first, third and seventh days after external drainage of the biliary tracts.

Patients were divided into two groups, depending on the bile flow on the first day after drainage of the biliary tract. Group I $(n=33)$ - patients with the total bile amount of up to $300 \mathrm{ml}$, group II $-(n=34-$ patients with the total bile amount of more than $300 \mathrm{ml}$ ). According to age and the level of indicators of functional activity of the liver during the investigation before drainage, the patients of both groups were comparable ( $p>0.05)$.

The statistical processing of the data was carried out using Statistica v.6.1 statistical software application (Statsoft Inc., USA, license number AJAR909E415822FA). The methods of descriptive and analytical biostatistics were used, in particular, the verification of the distribution of quantitative attributes for compliance with the normal law according to the criterion of Shapiro-Wilka. The critical level of statistical significance in checking all hypotheses was taken $<5 \%(\mathrm{p}<0.05)$ [7].

\section{RESULTS AND DISCUSSION}

When analyzing the results of external drainage of the biliary tract, it was determined that the most common complications were: bleeding into the abdominal cavity in 1 case $-1.5 \%$; dislocation of drainage tube in 1 case $-1.5 \%$. Violations of drainage were observed in 2 cases $-3.0 \%$ of patients.

The dynamics of the level of almost all investigated indicators of the functional state of the liver after external decompression of the biliary tract was not the same. So, after drainage of bile ducts different trend in the changes of levels of total bilirubin was observed (Fig. 1).

Patients in both groups showed a tendency to increase in the index on already the 1 st day after drainage of the biliary tracts. On the third day in patients of group I the level of the total bilirubin showed a tendency to decrease. At the same time in patients of group II the level of the index increased and decreased only on the 7th day after decompression of the biliary tract. It should be noted that the rates of the total bilirubin in patients of groups I and II on the $3 \mathrm{~d}$ and 7 th day differed significantly $(p<0.01)$.

In contrast to changes in the total blood serum bilirubin content, the level of its direct fraction during the examination tended to decrease, approximately, equally in patients of both groups (Fig. 2 ). 


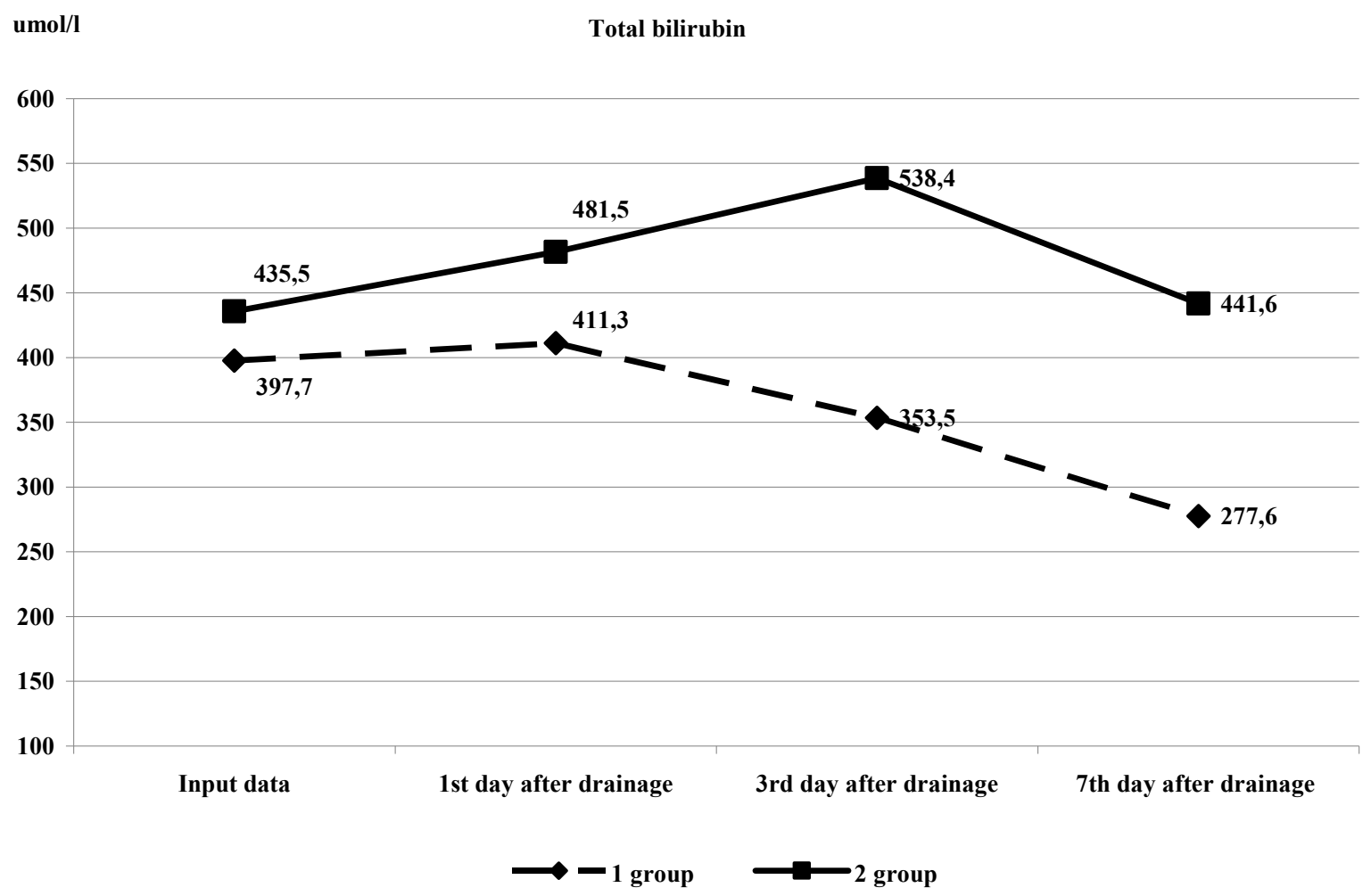

Fig. 1. Changes in the total bilirubin after external bile ducts drainage in both groups

The difference of changes in the level of direct bilirubin was not statistically significant $(\mathrm{p}>0.05)$.

After bile duct drainage, a different tendency to decrease in the level of indirect bilirubin was noted (Fig. 3).

On the first day there was a slight growth of indicators in both groups. However, on the third day in patients of group II, the level of indirect bilirubin was significantly higher $152.3 \pm 10.8 \mu \mathrm{mol} / 1$ than in the first group $94.3 \pm 7.9 \mu \mathrm{mol} / 1 \quad(\mathrm{p}<0.05)$. On the seventh day, the indicators decreased evenly to $77.9 \pm 7.1 \mu \mathrm{mol} / 1$ in group I and $123.9 \pm 9.2 \mu \mathrm{mol} / 1$ in group II $(\mathrm{p}<0.01)$.

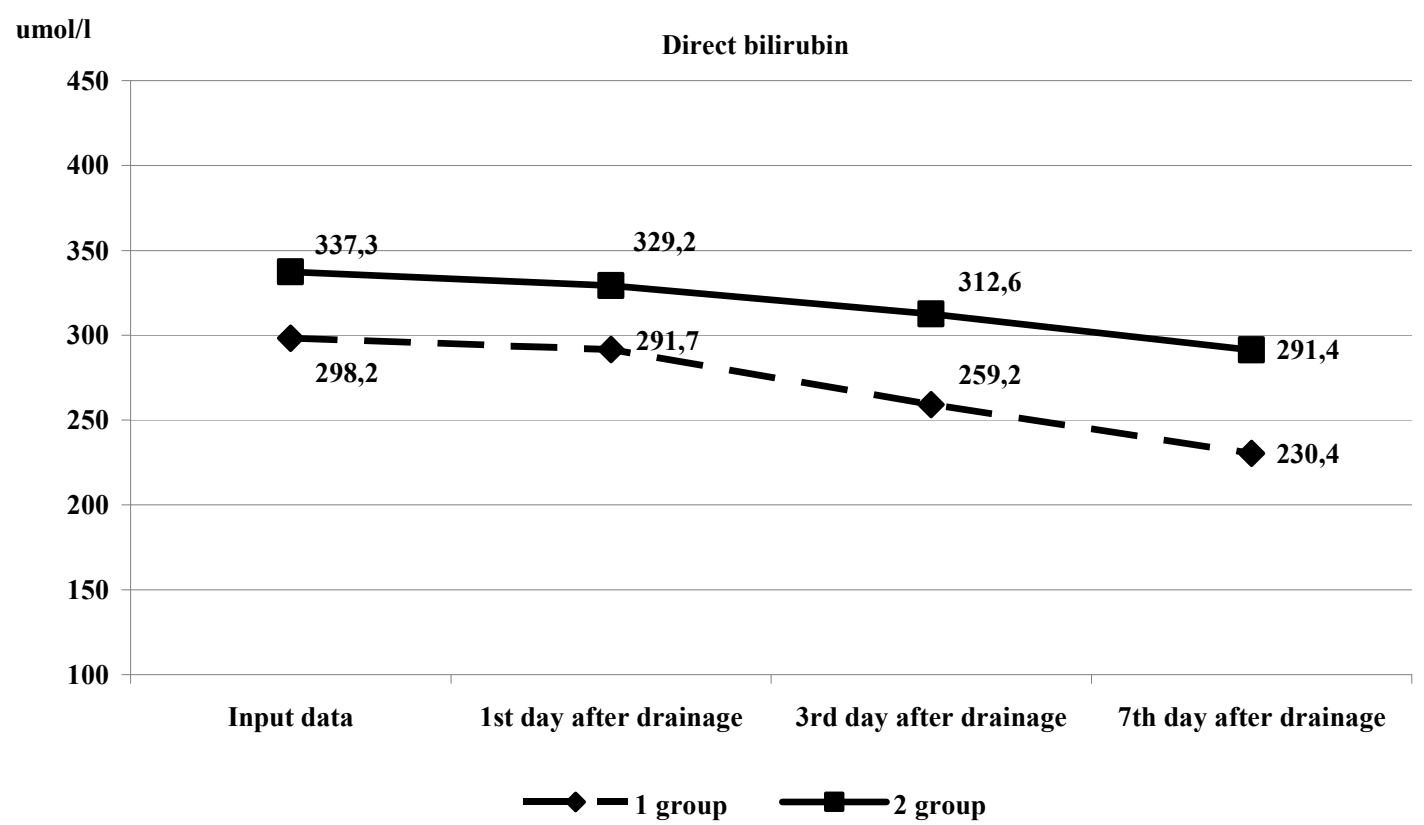

Fig. 2. Changes of indirect bilirubin after external bile duct drainage in both groups 


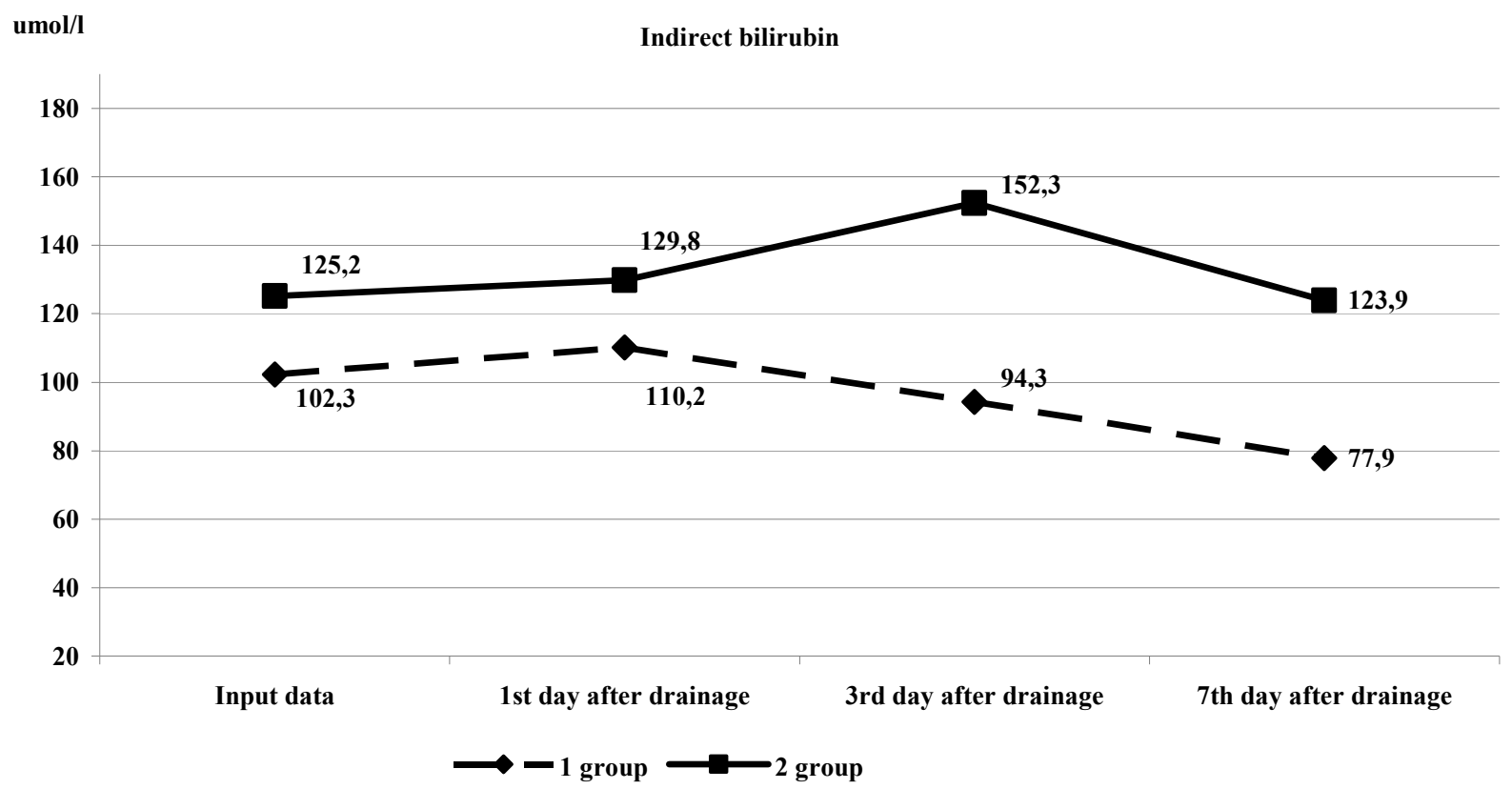

Fig. 3. Changes of indirect bilirubin after external bile duct drainage in both groups

The level of AST showed a similar trend (Fig. 4)

On the first day after drainage, there was a slight increase of the indicator in both groups. After that, the level of AST in patients of the first group began to decrease, and in the second group continued to rise till 3rd day, and only after this period it decreased. However, significant fluctuations in indicators were not observed $(\mathrm{p}>0.05)$.

The changes in ALT and ALP were similar (Figs. 5, 6).

$\mathrm{U} / \mathbf{l}$

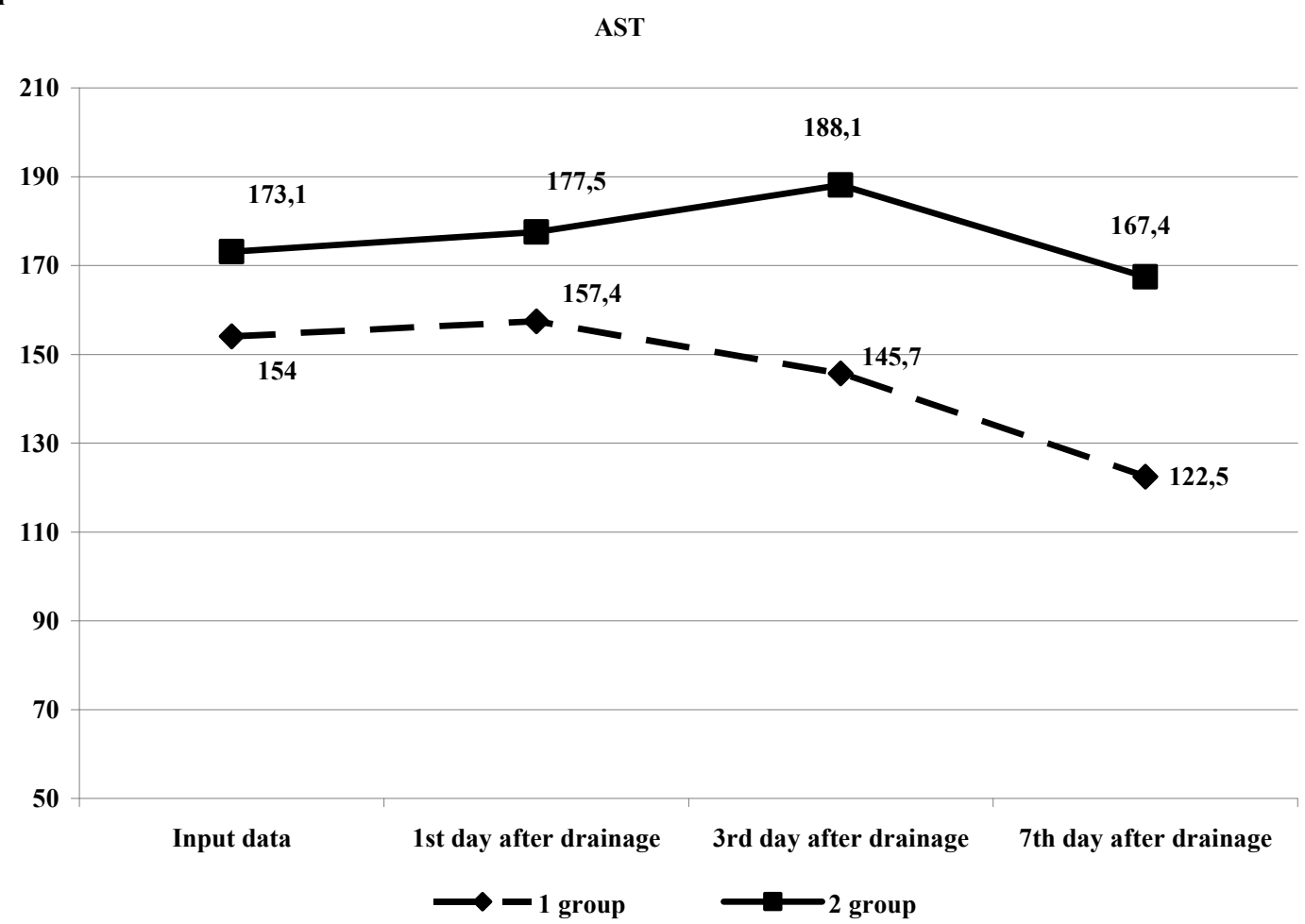

Fig. 4. Changes of AST after external drainage of the biliary tract in both groups 


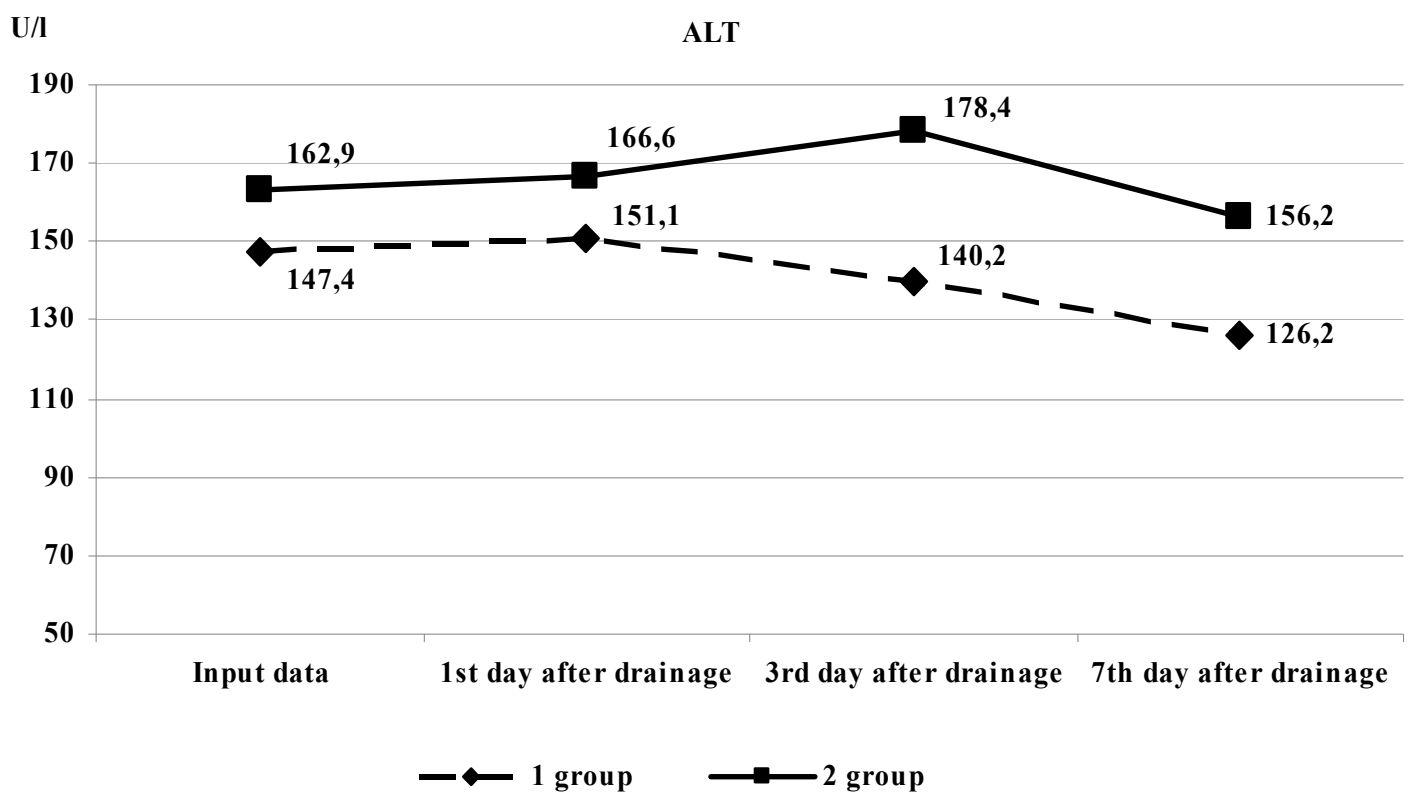

Fig. 5. ALT changes after external drainage of bile duct in both groups

On the first day after drainage there was a slight increase of the level of alkaline phosphatase in both groups. However, on the third day, patients of the group II had significantly higher rates $1698,5 \pm 113,9 \mathrm{U} / 1$ than in group I $-1204,4 \pm 101,2 \mathrm{U} / 1$ $(\mathrm{p}<0.01)$. By the seventh day, the indices began to decrease to $907,1 \pm 84,5 \mathrm{U} / 1$ in group $\mathrm{I}$, and $1501.3 \pm 97.2 \mathrm{U} / 1$ in group II $(\mathrm{p}<0.01)$.

According to the studies, indicator of the total bilirubin decrease for seven days directly correlated with bile flow $(\mathrm{rs}=0.51 ; \mathrm{p}<0.001)$.

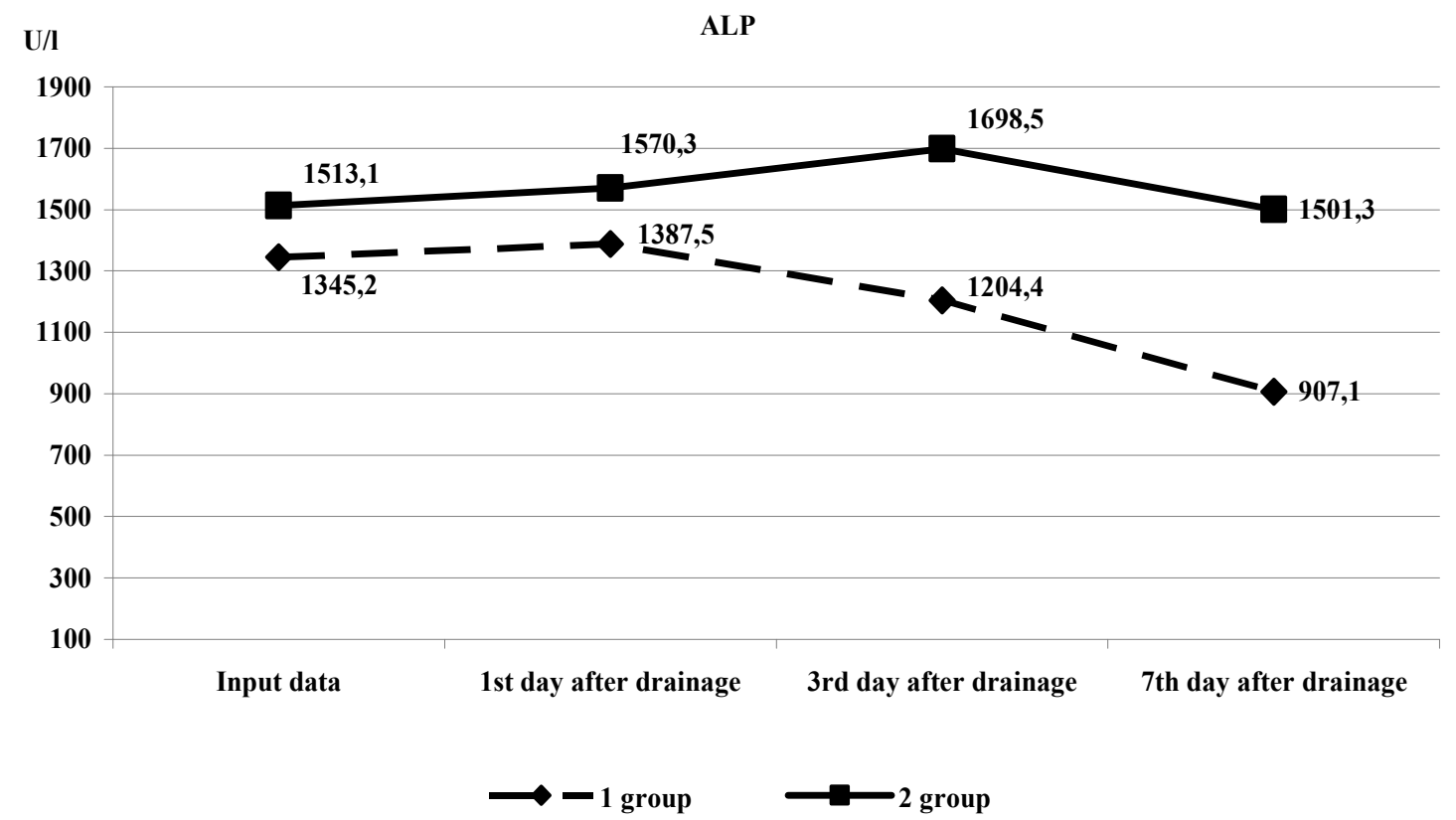

Fig. 6. Changes in ALP after external drainage of the biliary tract in both groups

The presented graphs clearly show that all group II than in group I over the same period of indicators decreased more slowly in patients of time. In addition, the loss of more than $300 \mathrm{ml}$ of 
bile in the first day after decompression of the biliary tract on the third stage of the study was accompanied by hyperenzymemia, which indicates the progression of hepatocyte cytolysis, and an increase in bilirubin levels due to indirect fraction in the liver. Thus, the degree of functional state of the liver after external decompression of the biliary tract directly depended on the daily amount of bile.

The results of the research show the dependence of the main indicators of the functional state of the liver on the loss of bile during the first day after external drainage of the biliary tract in patients with high level of mechanical jaundice. However, the evaluation of the significance of these changes in terms of the final results of treatment requires further analysis of the presented material. If the obtained data are really important, it is possible that it would be rational to artificially prevent the loss of a large amount of bile in the appropriate period after the drainage of the hepatic ducts or not to drain them at all, and to perform conditionally radical surgery at the height of jaundice.

\section{CONCLUSIONS}

Thus, bile flow (debit) on the first day after external drainage of biliary tract more than $300.0 \mathrm{ml}$, is a prerequisite for the development of hepatargia in the early period after biliary decompression.

The authors declare that there is no conflict of interest.

\section{СПИСОК ЛІТЕРАТУРИ}

1. Гальперин Э. И. Механическая желтуха: состояние" мнимой стабильности", последствия" второго удара", принципы лечения. Aнналь хирургической гепатологии. 2011. Т. 16, № 3. С. 16-25. URL: http://www.irbisnbuv.gov.ua/cgibin/irbis nbuv/cgii rbis_64.exe?C21COM=2\&I21DBN=UJRN\&P2 $1 \mathrm{DBN}=\mathrm{U}$ JRN\&IMAGE_FILE_DOWNLOAD $=1 \&$ Image_file_nam $\mathrm{e}=\mathrm{PDF} / \mathrm{Ujkh} 2013 \_3$ 34

2. Корекция печеночной дисфункции у больных при обтурационной желтухе / Б. М. Даценко и др. Клінічна хірургія. 2013. № 4. С. 9-12. DOI: https://doi.org/10.1002/hep.510300622

3. Кулезнева Ю. В., Израилов Р. Е., Капустин В. И. Тактика антеграднойбилиарной декомпрессии при механической желтухе опухолевого генеза. Becm. Hau. медико-хирургического иентра им. НИ Пирогова. 2010. T. 5, № 2. URL: https://cyberleninka.ru/article/n/taktikaantegradnoy-biliarnoy-dekompressii-pri-mehanicheskoyzheltuhe-opuholevogo-geneza

4. Методы декомпрессии билиарной системы в лечении больных с синдромом механической желтухи / А. Я. Мальчиков и др. Практ. медицина. 2011. № 49. URL: https://cyberleninka.ru/article/n/metody-dekompressii-biliarnoy-sistemy-v-lechenii-bolnyh-s-sindromommehanicheskoy-zheltuhi

5. Механическая желтуха: современные взгляды на проблему диагностики и хирургического лечения / Ю. А. Пархисенко и др. Укр. журнал хірургіï. 2013. № 3. C. 202-214. URL: http://www.ujs.dsmu.edu.ua/journals/2013-03/2013-03.pdf\#page $=202$
6. Ничитайло М. Ю., Огородник П. В., Дейниченко А. Г. Алгоритм диференційної і топічної діагностики механічної жовтяниці та мініінвазивної корекції прохідності магістральних жовчовивідних шляхів. Клін. хірургія. 2012. № 2. С. 5-10. URL: http://nbuv.gov.ua/UJRN/K1Kh_2012_2_3

7. Петров В. И. Базисные принципы и методология доказательной медицины. Вест. Волгоградского гос. медицинского университета. 2011. ‥ 38, № 2 URL: https://cyberleninka.ru/article/n/bazisnye-printsipyi-metodologiya-dokazatelnoy-meditsiny

8. Приоритетные направления в лечении больных с механической желтухой / Шевченко Ю. Л. и др. Аннальl хирургической гепатологии. 2011. Т. 16, № 3. С. 9-15. URL: http://www.vidar.ru/_getfile.asp?fid=ASH_2011_3

9. Diagnostic accuracy of MRCP as compared to ultrasound/CT in patients with obstructive jaundice / A. Singh et al. Journal of clinical and diagnostic research: JCDR. 2014. Vol. 8, No. 3. P. 103. DOI: https://doi.org/10.7860/jcdr/2014/8149.4120

10. Meta-analysis of randomized clinical trials on safety and efficacy of biliary drainage before surgery for obstructive jaundice / Y. Fang et al. British Journal of Surgery. 2013. Vol. 100, No. 12. P. 1589-1596. DOI: https://doi.org/10.1002/bjs.9260

11. Pre-operative biliary drainage for obstructive jaundice / Y. Fang et al. Cochrane database of systematic reviews. 2012. No. 9.

DOI: https://doi.org/10.1002/14651858.CD005444.pub3

\section{REFERENCES}

1. Gal'perin JeI. [Obstructive jaundice: a state of "imaginary stability", the consequences of a "second stroke", treatment principles]. Annaly hirurgicheskoy gepatologii. 2011;16(3):16-25. Russian. Available from: http://www.irbisnbuv.gov.ua/cgibin/irbis_nbuv/cgiirbis_6 4.exe? $21 \mathrm{COM}=2 \& \mathrm{I} 21 \mathrm{DBN}=\mathrm{UJRN} \& \mathrm{P} 21 \mathrm{DBN}=\mathrm{UJRN} \&$
IMAGE_FILE_DOWNLOAD $=1 \&$ Image_file_name $=P D$ F/Ujkh $2013 \overline{3} 34$

2. Dacenko BM, Borisenko VB, Tamm TI, et al. [Correction of hepatic dysfunction in patients with obstructive jaundice]. Klinichna hirurgiia. 2013;4:9-12. Russian. doi: https://doi.org/10.1002/hep.510300622 
3. Kulezneva JuV, Izrailov RE, Kapustin VI. [Tactics of antegrade biliary decompression in case of obstructive jaundice of tumor origin]. Vestnik Nacionalnogo mediko-hirurgicheskogo centra im. NI Pirogova. 2010;5(2):24-28. Russian. Available from: https://cyberleninka.ru/article/n/taktika-antegradnoy-biliarnoy-dekompressii-pri-mehanicheskoy-zheltuhe-opuholevogo-geneza

4. Malchikov AJa, et al. [Decompression methods of the biliary system in the treatment of patients with obstructive jaundice syndrome]. Prakticheskaia meditsina. 2011;2(49):84-87. Russian. Available from: https://cyberleninka.ru/article/n/metody-dekompressii-biliarnoy-sistemy-vlechenii-bolnyh-s-sindromom-mehanicheskoy-zheltuhi

5. Parhisenko JuA, et al. [Obstructive jaundice: current views on the problem of diagnosis and surgical treatment]. Ukrainskii zhurnal hirurgii. 2013;3:202-14. Russian. Available from: http://www.ujs.dsmu.edu.ua/journals/2013-03/2013-03.pdf\#page $=202$

6. Nichitailo Mju, Ogorodnik PV, Deinichenko AG. [Algorithm for differential and topical diagnosis of mechanical jaundice and minimally invasive correction of patency of the main biliary tract]. Klinichna hirurgiia. 2012;2:5-10. Ukrainian. Available from: http://nbuv.gov.ua/UJRN/K1Kh_2012_2_3
7. Petrov VI. [Basic principles and methodology of evidence-based medicine]. Vestnik Volgogradskogo gosudarstvennogo medicinskogo universiteta. 2011;2(38):3-8. Russian. Available from: https://cyberleninka.ru/article/n/bazisnye-printsipy-i-metodologiya-dokazatelnoy-meditsiny

8. Shevchenko JuL, et al. [Priority areas in the treatment of patients with obstructive jaundice]. Annaly hirurgicheskoi gepatologii. 2011;16(3):9-15. Russian. Available from: http://www.vidar.ru/_getfile.asp?fid=ASH_2011_3_9

9. Singh A, et al. Diagnostic accuracy of MRCP ascomparedtoultra-sound / CT in patients with obstructive jaundice. Journal of clinical and diagnostic research: JCDR. 2014;8(3):103.

doi: https://doi.org/10.7860/jcdr/2014/8149.4120

10. Fang Y, et al. Meta-analysis of randomized clinical trials on safety and efficacy of biliary drainage before surgery for obstructive jaundice. British Journal of Surgery. 2013;100(12):1589-96. doi: https://doi.org/10.1002/bjs.9260

11. Fang Y, et al. Pre-operative biliary drainage for obstructive jaundice. Cochranedata base of systematic reviews. 2012;9.

doi: https://doi.org/10.1002/14651858.CD005444.pub3

Стаття надійшла до редакції

27.06.2019 